Danmarks geologiske Undersøgelse.

II. Række. Nr. 28.

\title{
On Remains of
}

\section{Reindeer and Beaver}

from the commencement of the Postglacial Forest Period in Denmark.

\author{
With some remarks \\ upon other Danish quaternary mammals \\ by \\ V. Nordmann.
}

With a scheme:

The postglacial period in Denmark, compared with those of Norway and Sweden.

Kjøbenhavn.

I Kommission hos C. A. Reitzel.

Andelsbogtrykkeriet i Odense.

1915.

Pris : 75 Øre. 


\title{
Fortegnelse over Danmarks geologiske Undersøgelses Skrifter.
}

\author{
I. Række.
}

\section{Beskrivelser til Geologisk Kort over Danmark i Maalestok 1:100000.}

Nr. 1. K. Rørdam. Kortbladene Helsingør og Hillerød. 1893.

$-2,00 \mathrm{Kr}$.

- 2. N. V. Ussing og Victor Madsen. Kortbladet Hindsholm. 1897. - $2,00 \mathrm{Kr}$.

- 3. A. Jessen. Kortbladene Skagen, Hirshals, Frederikshavn, Hjøring og Løkken. 1899. - 6,00 Kr.

- 4. A. Jessen. Kortbladene Læsø og Anholt. 1897. - 1,50 Kr.

- 5. Victor Madsen. Kortbladet Samsø. 1897. - 1,50 Kr.

- 6. K. Rørdam. Kortbladene Kjøbenhavn og Roskilde. 1899.

- 4,00 Kr.

- 7. Victor Madsen. Kortbladet Bogense. 1900. - 2,00 Kr.

- 8. K. Rørdam og V. Milthers. Kortbladene Sejrø, Nykjøbing, Kalundborg og Holbæk. 1900. - 5,00 Kr.

- 9. Victor Madsen. Kortbladet Nyborg. 1902. - 4,50 Kr.

- 10. A. Jessen. Kortbladene Aalborg og Nibe (nordlige Del). 1905. - 4,50 Kr.

- 11. V. Milthers. Kortbladene Faxe og Stevns Klint. 1908. $-6,00 \mathrm{Kr}$.

- 12. A. Jessen. Kortbladet Skamlingsbanke. 1907. - 2,00 Kr.

II. R $æ k \mathrm{ke}$.

\section{Afhandlinger om specielle, videnskabelige og praktiske Emner.}

Nr. 1. K. Rørdam. Undersøgelse af mesozoiske Lerarter og Kaolin paa Bornholm i geologisk og teknisk Henseende. 1890 . $-1,25 \mathrm{Kr}$.

- 2. K. Rørdam. Saltvandsalluviet i det nordostlige Sjælland. 1892. $-3,00 \mathrm{Kr}$.

- 3. K. Røвdaм. Geologisk-agronomiske Undersøgelser ved Lyngby Landboskole og Brede Ladegaard. 1894. $1,00 \mathrm{Kr}$.

- 4. Henr Posselt. Brachiopoderne i den danske Kridtformation. 1894. - 1,25 $\mathrm{Kr}$.

- 5. K. Rørdam. Beretning om en geologisk Undersøgelse paa Frænnemark ved Svaneke paa Bornholm. 1895. $0,75 \mathrm{Kr}$. 
Danmarks geologiske Undersøgelse.

II. Række. Nr. 28.

\title{
On Remains of
}

\section{Reindeer and Beaver}

from the commencement of the Postglacial Forest Period in Denmark.

\author{
With some remarks \\ upon other Danish quaternary mammals \\ by \\ V. Nordmann.
}

With a scheme:

The postglacial period in Denmark, compared with those of Norway and Sweden.

Kjøbenhavn.

I Kommission hos C. A. Reitzel.

Andelsbogtrykkeriet i Odense.

1915. 


\section{Remains of reindeer.}

$\mathrm{T}$ he history of our mammalian fauna, which has now for many years, thanks to the work of Japetus STEenstrup ${ }^{1}$ in particular, been known in its rough outlines, has in course of time been largely supplemented by discoveries made during digging of marl pits, cutting of peat, and investigations of kitchen middens and ancient tumuli, of geologically interesting deposits and the like.

The additional knowledge furnished by recent investigations is not so much an augmentation of the number of species formerly known - although the demonstration of the existence in Denmark, in earlier times, of the fallow deer, Cervus dama, and probably also the Pika or rat-hare, Lagomys, must be considered as important - as a closer definition of the time at which the individual species immigrated and disappeared. It has thus been proved, that the beaver and the wolf are old inhabitants of this country, and were even to

${ }^{1}$ With regard to SteEnstrup's publications concerning Danish excavated remains of mammals, vide bibliography contained in the "Mindeskrift i Anledning af Hundredaaret for Japetus Steenstrups Fødsel «; udgivet af en Kreds af Naturforskere. Copenhagen 1914, and al-o Introduktion to H. Winge, 1904: Om jordfundne Pattedyr fra Danmark. Vidensk. Medd. Naturhist. Forening i København.

Up to the present, remains of 51 species of mammals have been obtained from the Danish quaternary strata; of these 18 (Spermophilus rufescens, Lepus variabilis, Castor fiber, Lagomys [hyperboreus?], Felis catus fera, Felis lynx, Canis lupus Ursus arctus, Trichechus rosmarus, Elephas primigenius, Sus scrofa ferus, Cervus giganteus, $C$ dama, Alces machlis, Rangifer tarandus, Ovibos moschalus, Bos taurus urus and Bos bison) have since become extinct in this country. As regards the large whales of which remains have been excavated, some few strayed specimens of all species have made their appearance in our waters in recent times; the Greenland seal from the far North, (Phoca groenlandica), bones of which have been found in several of our kitchen middens and in litorina deposits at Kolding, was also sighted off our coasts in 1903. The fallow deer (Cervus dama) has not existed here in a wild state since the last glacial period, and the wild hog (Sus scrofa ferus) was exterminated about the year 1800; both species have, however, since been introduced into our deer parks and game preserves, the fallow deer already in the Middle ages. 
be found here, together with reindeer and elk, as early as in the first temperature optimum after the glacial period, the so-called Allerød period. ${ }^{1}$ With regard to the division of the post-glacial time in Denmark see the scheme and page 22. It has further been shown that the elk was hunted by the earlier neolithic men who had their dwellings on the banks of lakes or narrow fjords [Maglemose, ${ }^{2}$ Skottemarke $^{3}$ and Brabrand lake, which was then a fjord ${ }^{4}$ ] but was already extinct when the hunting and fishing tribes of a somewhat later period settled down on the sea shore and there deposited the well known great refuse mounds of the neolithic age. ${ }^{5}$

As regards the fossil remains of our wild ox species, it would appear to be still beyond doubt that the bison has been considerably more rare than the urus, since no remains of bison have been found in Denmark beyond two fragmentary skulls, the first of which was discovered in 1852 at Baldersbrønde in Sealand and the other several years later in Miang bog at the island Als, ${ }^{6}$ at the east coast of Slesvig, whereas numerous remains of urus indicate that this species must have been common throughout the whole of the country. It was doubtless exterminated, howewer, as early as the Stone Age.

It may also be noted that the pole cat (Mustela putorius) now only living in Jutland, was formerly also to be found in Funen and Sealand, whereas on the other hand the hare (Lepus curopaus Pallas), which is now common all over the country, would seem to have been more rare in the Stone Age, probably owing to the predominance of forest which would ill accord with the habit of this

${ }^{1}$ N. Hartz og V. Milthers, 1901: Det senglaciale Ler i Allerød Teglværksgrav. Medd. Dansk geol. Forening Vol. 1. No. 8. P. 55.

N. Hartz, 1902: Bidrag til Danmarks senglaciale Flora og Fauna. Danm. geol. Undersøgelse II. R. No. 11. P. 22-24.

N. Hartz, 1912: Allerød Gytje und Allerød Mull. Meddel Dansk geol. Forening. Vol. 4. P. 88.

${ }^{2}$ Georg F. L. Sarauw, 1904: En Stenalders Boplads i Maglemose ved Mullerup. Études sur le premier âge de la pierre du Nord de l'Europe. Aarb. f. nord. Oldk. og Hist. 1903.

${ }^{3}$ Herluf Winge, 1904: Om jordfundne Pattedyr fra Danmark. Vidensk. Meddel. fra naturhist. Forening i Kbhvn. P. 207 and 271-72.

${ }^{4}$ Thomas Thomsen og A. Jessen, 1906: Brabrand-Fundet fra den æeldre Stenalder. Aarb. f nord. Oldk. og Hist. 1906.

${ }^{5}$ Herluf Winge and others, 1900: Affaldsdynger fra Stenalderen i Danmark. P. 185.

${ }^{6}$ V. Nordmann, 1914: En fossil Pandeskal af Bison europæus fra en Mose paa Als. Vidensk. Meddel. Naturhist. Forening i Kbhvn. Vol. 66. P. 229.

It is in all probability this cranium which JAP. STEENSTRuP had in mind when referring, in two of his publications, somewhat indistinctly to two finds of bis on in l)enmark. 
denizen of the steppes or the open fields. ${ }^{1}$ Of the ground squirrel (Spermophilus rufescens) again, no remains have been found save the lower jaw discovered by JAP. Stennstrup in 1877 in a fresh water deposit at Nørre Lyngby in Vendsyssel, which probably belongs to the beginning of the alluvial forest period, and is thus a little younger than the uppermost parts of the later glacial deposits at Allerød in North Sealand, the so called »upper« or »younger« Dryas clay, where excrements presumed to be those of the rat hare ( $\mathrm{La}$ gomys) have been found. ${ }^{2}$ And finally as regards the investigation of our interglacial strata, these have been found to contain bones or other traces of the following mammals: red deer, elk, ${ }^{3}$ fallow deer, beaver, squirrel, mouse (wood mouse), and probably rat-hare and Irish deer. ${ }^{4}$

1 Herluf Winge and others, 1909: Affaldsdynger . . . . P. 181-82.

Herluf Winge, 1908: Pattedyr. Danmarks Fauna ..... udg. af Naturhist. Forening, København. P. 60 and 136.

${ }^{2}$ With regard to the peculiar little Birch Mouse (Sminthus subtilis) still living in Jutland, the geographical distribution of which is so remarkable, it should be mentioned that no fossil remains of this have ever been found either in Denmark or in the countries closely adjacent. Another isolated occurrence of the living animal has however been recorded in 1907 , in the mountain tracts of Southern Norway, where the species lives in the open land above the wood region. (Vide R. ColletT: Sicista subtilis in Norway. Christiania Vidensk. Forh. f. 1909.) Its true habitation, it will be remembered, is in Hungary, Poland, Russia, South Finland and Siberia, where it is found in the fringe of woods along the border of the steppes. It has been found in a fossil state in quaternary løss deposits at Nussdorf, near Vienna, together with Lagomys, Spermophilus and other steppe species. (A. Nehring, 1879: Fossilreste kleiner Säugetiere aus dem Diluvium von Nussdorff bei Wien. Jahrb. d. k. k. geolog. Reichsanst. in Wien.)

${ }^{3}$ An antler of the red deer, Cervus elaphus, and three molars of the $\mathrm{elk}$, Alces machlis, have been found in an interglacial fresh water deposit at Hørrup, $16 \mathrm{~km} \mathrm{~N}$ of Viborg, (vide N. V. Ussing, 1907: Om Floddale og Randmoræener i Jylland. Oversigt. Kgl. Danske Vidensk. Selsk. Forhandl. P. 207; and N. V. Ussing, 1910: Dänemark, Handbuch der regionale Geologi 1. Bd. 2. Abt. (P. 20.)

The bones were determined as to species by Inspektor H. WingE, who has kindly permitted me to make mention of these hitherto unpublished finds.

${ }^{4}$ V. Nordmann, 1905: Danmarks Pattedyr i Fortiden. Danm. Geologiske Undersøgelse. 3. R. Nr. 5. P. 20-29.

N. Hartz, 1908: Bidrag til Danmarks tertiære og diluviale Flora. With an English summary of the contents. D. G. U. II. R. No. 20. P. 249-52 and 289 -90. The only traces which could seem to indicate the earlier occurrence of Lagomys in Denmark are some small excrements, now lense-shaped, but doubtless originally spherical, which exhibit remarkable agreement in size and appearance with excrements of Lagomys from South Russia and Altai. They were found partly in cakes of vegetable matter: - old tundra surfaces - in the uppermost boulder clay at kolding, partly in the late glacial fresh water 
Nevertheless, it cannot be denied that a number of queries still remain to be answered concerning the immigration and disappearance of our mammals, their distribution and frequency in different parts of the country, etc. One point which may be regarded as of especial interest is the question as to how long the reindeer continued to exist here in Denmark.

The earliest information as to excavated remains of reindeer in Denmark is probably that contained in the report published by $\mathrm{J}$. H. REINHARDT ${ }^{1}$ of a cast reindeer antler, found at a depth of 1,73 metres, $\left(5^{1 / 2} \mathrm{ft}\right.$.) beneath the surface of the soil, and sunk to an inconsiderable degree in (late glacial) marl under a peat bog near Bregentved in South Sealand. Taking in to consideration this find, which is excellently described in view of the time at which it was made, it must seem strange that $\mathrm{J}_{\mathrm{AP}}$. Steenstrup in 1842 should be of opinion that reindeer lived here in the $\gg$ oak period $\ll{ }^{2}$ He himself states that remains have at times been found in bogs; it can, however, certainly not have been in strata from the »oak period ", for neither he nor anyone else has ever subsequently found such in deposits which can with certainty be classified as belonging to that period. In 1869 he states $^{3}$ that remains of reindeer are but rarely found in the peat itself, but occur more frequently in the strata immediately beneath, principally (as shown in his figures) in late glacial clay, snail marl and aspenlayer. In 1880 Steenstrup arrived at the conclusion ${ }^{4}$ that $\gg$ as far any comparatively reliable data were available concerning the position occupied by remains of reindeer, it was beyond doubt that

clay at Allerød. There is every reason to believe that they are those of $L A$. gomys hyperboreus Pallas. No sufficient information is available as to the strata in which the two remains of the Irish deer, Cervus giganteus, in Denmark (Funen and Sealand) were found; in all probability, however, they were taken from loose flakes of interglacial peat, enclosed in boulder clay.

${ }^{1}$ Oversigt kgl. danske Vidensk. Selsk. Forhandl. for 1836-37. P. 7.

2 Jap. Steenstrup, 1842: Geognostisk-geologisk Undersøgelse af Skovmoserne Vidnesdam og Lillemose. Vid. Selsk. naturvid. og mathm. Afh. IX. Del. P. 119.

${ }^{3}$ Jap. Steenstrup, 1872: Sur les Kjøkkenmøddings de l'âge de la pierre et sur la faune et la flore préhistoriques de Danemark. Extr. des bulletins du Congres Internationale d'Archæologie préhistorique á Copenhague 1869. P. $161-62$. cf. P. 139 and 170.

${ }^{4}$ Jap. Steenstrup, 1880: Nogle i Aaret 1879 til Universitets-Museet indkomne Bidrag til Landets forhistoriske Fauna. Oversigt Vid. Selsk. Forhandl. for 1880 p. 143: "forsaavidt vi havde nogenlunde sikre Data om det Leje, som Levningerne af Rensdyret havde indtaget, var det utvivlsomt, at de hidrørte fra Strata, der vare langt ældre end Landets Fyrrevegetation, og flere af dem kunde jeg ved Iagttagelse paa selve Stedet med største Bestemthed føre tilbage til selve Lagene med de arktiske Plantelevninger.» 
they originated from strata far older than the fir vegetation of the country, and in many instances I could, by examination on the spot, place them with the greatest certainty as far back as the strata containing remains of Arctic vegetation «. Finally, in 1886 he points out that $»$ die Ueberreste der Renntiere hingegen $\ll$ - i. e. in contrast to the bones of elk - »insofern ihre Lage hat zuverlässig bestimmt werden können, nur in den die Pflanzen der Alpenvegetation enthaltenden Schichten vorkommen ${ }^{1}$ Whether Steenstrup had here forgotten the reindeer bones from the bogs to which he referred in 1842 , or whether he was no longer disposed to trust to the information which he had then obtained as to the conditions under which they were found, it is not easy to say.

Herluf Winge ${ }^{2}$ likewise points out, that »in nearly all cases where any information has been available as to which of the (post glacial) bog layers remains of reindeer were found in, it has been proved to be marl surmounted by peat, in the oldest bog deposits from the time nearest the glacial period. Some few remains appear, however, to have been taken from the peat itself, « — which after all would hardly be surprising, considering the distribution of the species in our own times. The reindeer is by no means restricted to the treeless mountain regions and wide tundras, the character of which approximately resembles that which we must suppose to have been prevalent in Denmark at the time when the arctic plants flourished here, and the late glacial marl strata beneath the bogs were deposited; both in the old and the new world, reindeer are also found in the northern wooded regions. In America it penetrates southward as far as New Brunswick, Maine, and Nova Scotia and the latitude of the northern banks of Lake Superior, and is also found in Newfoundland. In Finland it wanders during winter as far as lake Ladoga, and from Russia, it was announced in 1881 that »some few specimens of reindeer may still not infrequently stray down to the Waldai nountains in the government of Novgorod, and are hunted there «. It also occurs in the forests of the Ural (or has only recently been driven thence), and in Siberia it is encountered throughot the whole extent of the forest region. ${ }^{3}$

${ }^{1}$ Jap. Steenstrup, 1886: Kjøkkenmøddinger. Eine gedrängte Darstellung dieser Monumente sehr alter Kulturstadien. P. 20.

${ }^{2}$ Herluf Winge, 1904: 1. c. P. 285: "I næsten alle de Tilfælde, hvor noget har været oplyst om, i hvilke af Mosernes Lag de mosefundne RensdyrLevninger har været lejrede, har det vist sig, at det var i Mergel under Tørv, i Mosernes ældste Aflejringer fra Tiden nærmest Istiden. Enkelte Levninger synes dog at være fundne i Tørv.»

${ }^{3}$ Madison Grant, 1902: The Caribou. Seventh Annual Report of the New York Zoological Society.

[To be continuated on the next page.] 
The reindeer being thus a member, not only of the tundra fauna, but also of the forest fauna of the northern hemisphere, there would be nothing extraordinary in the finding of its remains in the actual peat or "gytie « layers of our bogs; but of all the finds (some 75) of reindeer remains hitherto made in Denmark, only two or three can be said to belong to the alluvial period, the time when the tundra had given place to a more or less close vegetation of thicket and forest.

Of these three finds, that as to which least is known with regard to geological position is one made at Sejrø, NW of Sealand, in 1902, and briefly referred to by N. HARTz and H. Winge. ${ }^{1}$ In the middle of January of that year, the late A. Peterses, parish bailiff, found at Svaleklint, on the north side of Sejrø, some remains of peat lying on the shore above the normal water level. On closer examination, he found in the peat a fragment of a reindeer antler, naturally shed. The spot was subsequently visited by him in company with the State Geologist V. Milthers, and it was found, that the peat fragments originated from a postglacial bog situated on the beach, and extending out under the water. Several other submarine bogs are known from the neighbourhood of Sejrø. Unfortunately, the peat has not been subjected to closer examination, and nothing can therefore be said as to the trees of which the forest was composed at the time when the peat stratum was formed. The antler had apparently lain undisturbed in its original position. According to information furnished by Mr. Petersen, the half of a reindeer horn was found some years earlier on the island in a peat bog, covered with sand (sea sand?) not far from the spot where the antler referred to was found.

Considerably fuller information is available as to the position of a reindeer antler found in 1905 at Kjellerup (Funen) and sent in to the Geological Survey of Denmark by Dr. Ønsted of Ringe. ${ }^{2}$ The find was made in the course of some ditching work in boggy ground by the farmer Mr. N. Bruun, and was stated to have been broken

C. Struckmann, 1881: Ueber die Verbreitung des Rentiers. Zeitschr. d. deutsch. geolog. Gesellsch. Bd. 32 (Jahrg. 1880). P. 730 and 741. „Einzelne Individuen des Rentiers verlaufen sich noch jetz nicht selten bis in die Waldaiberge des Gouvernements Nowgorod und werden dort gejagd."

Alfred Nehring, 1890: Ueber Tundren u. Steppen der Jetzt- und Vorzeit. Berlin.

A. E. Brehm, 1890: Vom Nordpol zum Equator (Danish Edition: „Naturliv«, by L. Stange, Copenhagen, 1892. P. 108).

${ }^{1}$ N. Hartz, 1902 : l. c. p. 45.

Herluf Winge, 1904: 1. c. p. 283.

${ }_{2}^{2}$ The find is briefly referred to in V. Nordmann, 1905: Danmarks Pattedyr i Fortiden. Danm. geol. Undersøgelse, III. R. Nr. 5, p. 63. 
loose from the soil. It was this definite statement as to the manner in which it was removed which gave rise to the idea that further remains of the animal might well be still embedded in the earth, wherefore the author was entrusted with the task of making an investigation on the spot.

The site was at the eastern point of a small oblong bog pit lying between hills of boulder clay some $2200 \mathrm{~m}$. S. E. of the church at Ringe. The greater part of the upper peat layer had been cut away; the remainder, $0,40 \mathrm{~m}$ thick, consisting of highly decomposed peat with a considerable admixture of sand and clay, contained remains of oak, alder, hazel etz. Beneath this was $0,35 \mathrm{~m}$ of greyish brown gytie, and below this again $0,22 \mathrm{~m}$ of compact moss peat (Amblystegium peat); the fresh surfaces of this last were of a light yellowish brown or amber colour; after having remained for some time exposed to the action of the air, however, the peat became almost black. A quantity of birch and aspen twigs were found in this layer, as well as a number of seeds of buck bean (Menyanthes). The antler had been found at the surface of this layer immediately below the gytie, half embedded in the former, at a depth of $0,75 \mathrm{~m}$ below the surface of the soil, and the excavation now made distinctly revealed the impression of the horn in the surface of the peat. The ground was dug up on all sides for some distance round to the spot where it had lain, but nothing was found with exception of the flat ends of the horn. It was the breaking off of these which had given rise to the supposition that something more might still be remaining in the peat. In order to obtain some idea as to the sequence of the strata in the bog and their fossil contents, I had a further excavation made immediately beside the spot where the upper end of the antler had been found.

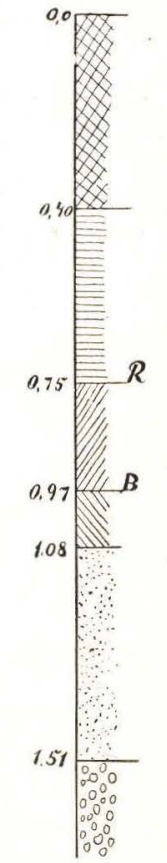

Fig. 1. Section in the bog at Kjellerup, SE of Ringe, Funen. $B$ indicates the place of the reindeer antler, B that of the twig gnawed by beaver, see on p. 19.

The following profile (vide Fig. 1) was thus obtained:

$0-0,40 \mathrm{~m}$ peat highly decomposed, the upper part with some admixture of clay and sand.

0,40-0,75 m greyish brown gytie, with some few stones.

0,75-0,97 m Amblystegium-peat containing twigs, seeds of Menyanthes etc.

0,97-1,08 m light greyish brown gytie. 
1,08-1,51 m light grey fresh water clay with shells of Sphcrium corneum and Pisidium in small heaps close to the juncture with the gytie layer above.

1,51- $\mathrm{m}$ gravel and sand, with much water; between 0,5 and $1 \mathrm{~m}$ thick, with boulder clay beneath.

The inflow of water from the sand between the fresh water clay and the boulder clay was so strong as to render it impossible to make accurate measurement or investigation of the lower part of the profile. In the course of the excavation, samples of each stratum were taken, and examined by N. HARTz, who has dealt with the remains of flowering plants therein found (vide list). The fresh water diatoms noted in the list have been determined by E. Østrup, the mosses by A. Hesselbo.

\begin{tabular}{|c|c|c|c|c|c|c|c|}
\hline Plants & 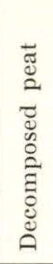 & 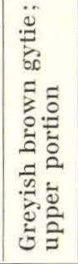 & 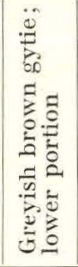 & 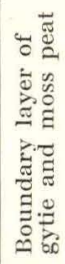 & 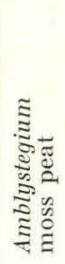 & 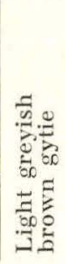 & 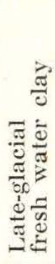 \\
\hline \multicolumn{8}{|l|}{ Angiospermae. } \\
\hline Alnus glutinosa Gärtn.............. & x & . & ․ & $\cdots$ & $\cdots$ & . & \\
\hline Arctostaphylos sp.............. & . & $\cdots$ & . & . & $\cdots$ & $x$ & $\times$ \\
\hline Batrachium cfr. confervoüdes Fr. ..... & . & x & $\cdots$ & $\cdots$ & $\cdots$ & $\therefore$ & \\
\hline Betula nana $L . \ldots \ldots \ldots \ldots \ldots \ldots$ & & $x$ & $x$ & $\cdots$ & $\cdots$ & $x$ & $x$ \\
\hline $\begin{array}{l}\text { Betula odorata Bechst. . . . . . . . } \\
\text { Callitriche autumnalis } L \ldots \ldots \ldots \ldots\end{array}$ & $x$ & $\times$ & $x$ & . & $\ldots$ & $\begin{array}{c}x \\
\ldots\end{array}$ & $\times$ \\
\hline 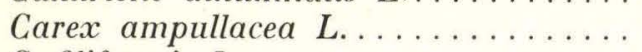 & . & $x$ & $x$ & $x$ & $\cdots$ & $x$ & $x$ \\
\hline C. filiformis $L \ldots \ldots \ldots \ldots \ldots \ldots \ldots$ & x & $\cdots$ & $\cdots$ & & . & . & \\
\hline Comarum palustre Scop............ & & . & . & $x$ & . & . & \\
\hline Corylus avellana $L . \ldots \ldots \ldots \ldots \ldots$ & $x$ & . & . & . & & . & \\
\hline Dryas octopetala L. .............. & & & . & & . & $\cdots$ & x \\
\hline Menyanthes trifoliata $L . \ldots \ldots \ldots \ldots$ & x & $x$ & $x$ & $x$ & x & $\cdots$ & . \\
\hline $\begin{array}{l}\text { Myriophyllum spicatum } L . \ldots \ldots \ldots \\
\text { Nymphaea alba } L .\end{array}$ & $\ddot{x}$ & $\times$ & $\times$ & $x$ & & $\frac{x}{x}$ & x \\
\hline 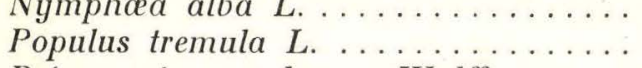 & $x$ & & & $\cdots$ & $\ddot{x}$ & & $\cdots$ \\
\hline Potamogeton praelongus Wulff.... & & x & $\times$ & $x$ & $\cdots$ & $x$ & $x$ \\
\hline P. $s p \ldots \ldots \ldots \ldots \ldots \ldots \ldots \ldots$ & x & x & . & $x$ & x & $x$ & $x$ \\
\hline Quercus pedunculata Ehr...... & x & . & $\cdots$ & & & . & . \\
\hline Rubus idous L. ............. & x & & 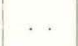 & & $\cdots$ & . & . \\
\hline Rumex $s p . \ldots \ldots \ldots \ldots \ldots \ldots \ldots \ldots$ & x & $\cdots$ & & . & & . & \\
\hline Salix reticulata $L . \ldots \ldots \ldots \ldots \ldots$ & .. & . & $x$ & $\cdots$ & $\because$ & $\cdots$ & . \\
\hline $\begin{array}{l}\text { Sparganium } s p . \ldots \ldots \ldots \ldots \ldots \ldots \ldots \\
\text { Umbelliferae }\end{array}$ & . & . & . & . & $\times$ & . & $\because$ \\
\hline Umbelliferae...................... & & & & & & & \\
\hline
\end{tabular}




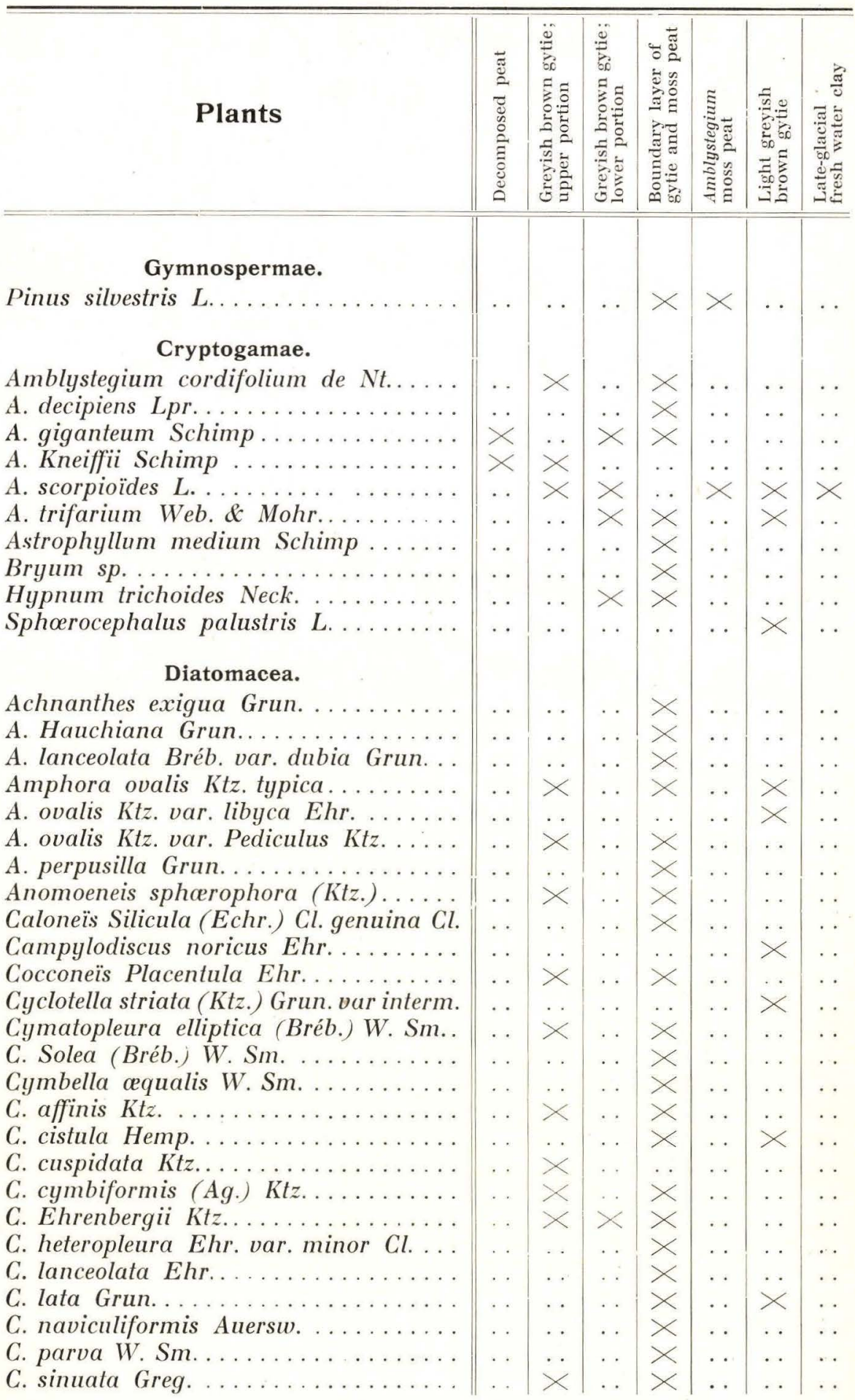




\begin{tabular}{|c|c|c|c|c|c|c|c|}
\hline Plants & 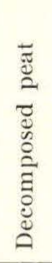 & 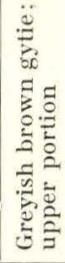 & 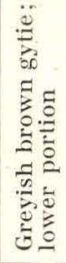 & 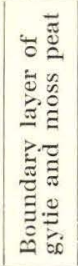 & 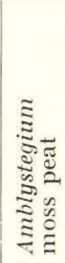 & 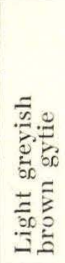 & 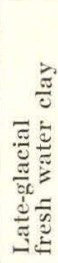 \\
\hline C. ventricosa Ktz. $f$. & & & & & & & \\
\hline C. ventricosa Ktz., var ovata Grun ... & $\cdot$ & $\cdots$ & $\cdots$ & & $\cdots$ & $\ldots$ & $\ldots$ \\
\hline 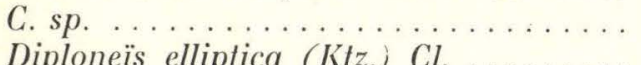 & . & $\cdots$ & . & & . & . & . \\
\hline $\begin{array}{l}\text { Diploneis elliptica } \mathrm{Ktz} . \text {. Cl. } \\
\text { Epithemia sorex Ktz........ }\end{array}$ & . & $x$ & . & $\begin{array}{l}x \\
x\end{array}$ & . & . & . \\
\hline 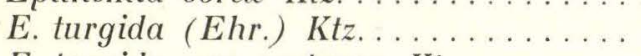 & & $\cdots$ & $\cdots$ & & . & . & . \\
\hline E. turgida var. vertagus $K t z . \ldots \ldots \ldots$ & . & $\cdots$ & 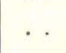 & $x$ & . & $\cdots$ & . \\
\hline E.zebra(Ehr.)Ktz.var.proboscoüdeaGrun. & . & $\cdots$ & & & · & $\cdot$ & . \\
\hline $\begin{array}{l}\text { Eunotia gracilis (Ehr.) Rabh........ } \\
\text { E. pectinalis (Ktz.) Rabh........... }\end{array}$ & & $\ldots$ & $\begin{array}{l}\cdots \\
\cdots\end{array}$ & $\times$ & $\begin{array}{l}\cdots \\
\therefore\end{array}$ & . & . . \\
\hline E. pectinalis uar. stricta Rabh....... & $\cdots$ &. & . & $x$ & $\ldots$ & . & $\ldots$ \\
\hline Fragilaria brevistriata var. pusilla Grun. & & & & $x$ & . & . & . \\
\hline F, capucina var. mesolepta Rabh...... & . & & & $\times$ & . & $\cdots$ & . \\
\hline F. construens (Ehr.) Grun........... & . & $\times$ & $x$ & $x$ & . & $x$ & . \\
\hline F. construens var. binodis Grun....... & . & . & . & $x$ & . & $\times$ & . \\
\hline F. construens var. venter Grun........ & . & . & . & $\times$ & . & $\ldots$ & . \\
\hline F. Harrisonii Grun. . . . . . . . . . . & . & . & $\cdots$ & $\times$ & . & $x$ & . \\
\hline F. inflata Pant..... & . & & & $x$ & . & . & $\cdots$ \\
\hline F. mutabilis (W. Sm.) Grun............ & & $x$ & $x$ & & . & $\begin{array}{l}x \\
x\end{array}$ & $\cdots$ \\
\hline $\begin{array}{l}\text { F. mutabils var. elliptica Schum...... } \\
F \text {. mutab. var. elliptica } f \text {. minor . . . . }\end{array}$ & $\ldots$ & $\ddot{x}$ &. & $\times$ & $\cdots$ & $\begin{array}{l}x \\
\ldots\end{array}$ & $\cdots$ \\
\hline Gomphonema acuminatum Ehr. ..... & . & $x$ & . & $x$ & $\cdots$ & $\cdots$ & $\cdots$ \\
\hline G. acum, var. Brébissonii Ktz. . . . . & . & $\cdots$ & . & $<$ & - & $\cdots$ & . \\
\hline G. constrictum Ehr. ............. & . & . & . & $<$ & . & $\cdots$ & . \\
\hline G. constr. var. capitata Ehr. . . . . . & $\cdots$ & & · & & $\cdots$ & $\cdots$ & . \\
\hline G. gracile var. naviculoides W. Sm.... & $\cdots$ & & & & . & $\cdots$ & . . \\
\hline 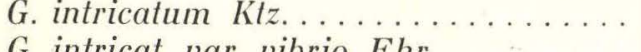 & . & & & & . & $x$ & .. \\
\hline $\begin{array}{l}\text { G. intricat. var. vibrio Ehr. } \\
\text { G. parvulum var. micropus }\end{array}$ & . & $\times$ & $\ldots$ & & & . & $\ldots$ \\
\hline G. subtile var. sagitta Schum. & . & . & $\cdot$ & $\times$ & . & . & . \\
\hline G. tenellum Ktz.......... & . &. & $\cdots$ & $\times$ & . & & 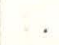 \\
\hline Mastogloja sp. ....... & . & . & . & $\cdots$ & . & $x$ & \\
\hline Melosira granulata (Ehr.) Ralfs. & . & . & & & & $x$ & . \\
\hline Meridion circulare (Grev.) Ag. . & . & & $x$ & & & $x$ & \\
\hline Navicula anglica Ralfs.......... & . & $x$ & & $\times$ & & $\cdots$ & . \\
\hline N. bacilliformis Grun.......... & . & & . & $\times$ & . & $x$ & . \\
\hline N. Bacillum Ehr. var. minor. . & & $x$ & . & & & . & . \\
\hline N. cuspidata Ktz. . . . . & . & . & & $x$ & & . & \\
\hline N. dicephala (Ehr.) W. Sm. . & . & . & & $x$ & & . & . \\
\hline 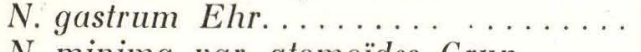 & ․ & . & & x & · & . & $\cdots$ \\
\hline N. minima var. atomoïdes Grun. & . & & & $x$ & . & $\cdots$ & 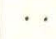 \\
\hline N. oblonga Ktz.................. & & $x$ & & $x$ & & $\ldots$ & \\
\hline
\end{tabular}




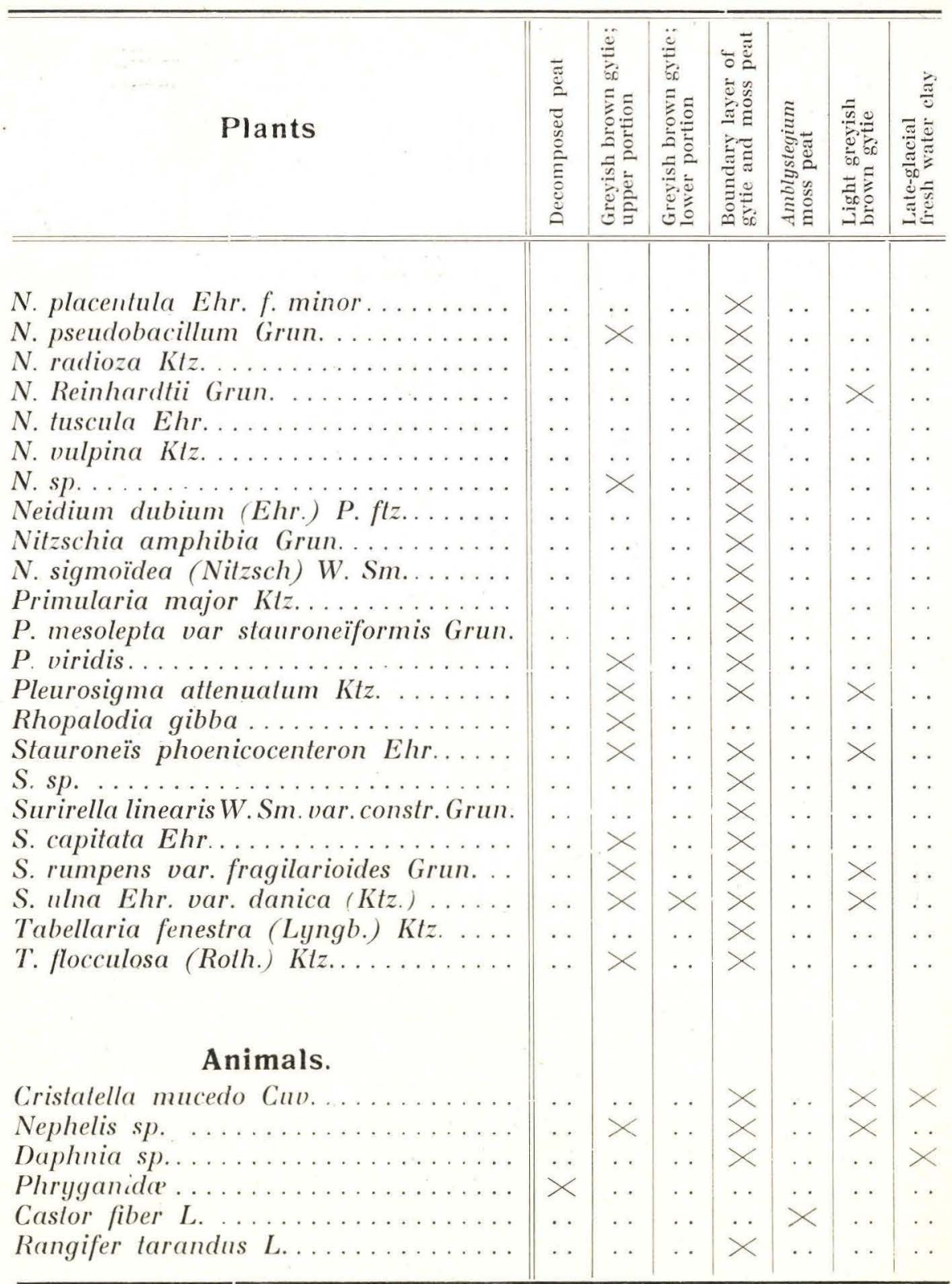

It should be especially mentioned that neither the upper layer of pure gytie nor the moss peat contained any such admixture of clay, sand or gravel in masses as would support the theory that the antler might have been shifted by some landslip down into the bog from the slopes of the surrounding hills; it lay quite evidently in its primary situation at the juncture of the upper gytie stratum and the 
moss peat beneath. The remains of plants found in the different strata indicate, not only that the reindeer to which the horn belonged must have lived at a period long after the place had been overgrown with birch and aspen; the quantity of fir (Pinus silvestris) pollen found in the boundary layer where the antler lay, as well as far down in the lowest part of the moss peat, further show that the animal in question was living there at least in the beginning of the fir period; the pollen would hardly have been distributed as it was throughout

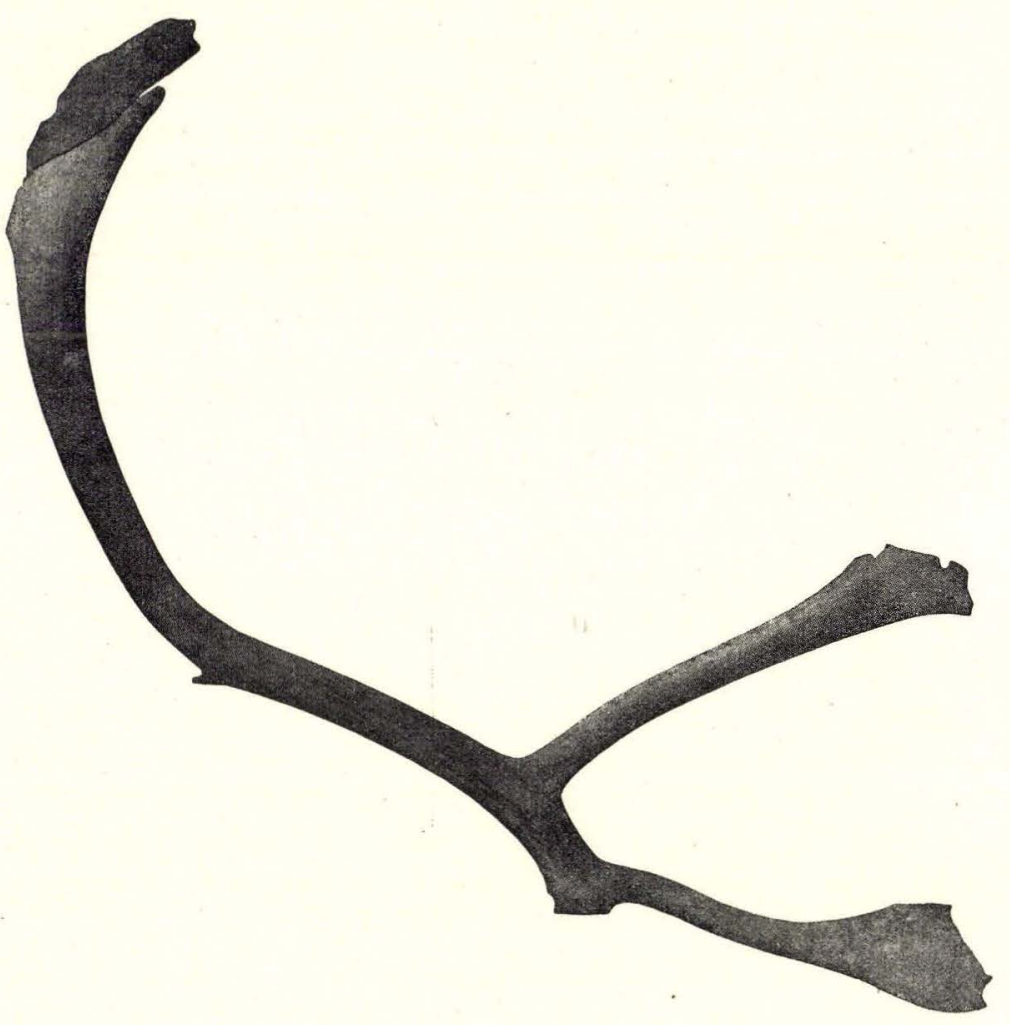

Fig. 2. Right antler of Rangifer tarandus L. from Kjellerup, SE of Ringe, Funen. $1 / 8$ nat. size.

so large a portion of series of strata unless the firs had been growing in the environs of the bog.

The dimensions of the reindeer antler from Kjellerup, shown in the accompanying Figure 2, are as follows: The distance in direct line from the top to the root $0,8 \mathrm{~m}$. Length of the beam from top to root $1 \mathrm{~m}$. Circumference of the beam under the brow tine $0,15 \mathrm{~m}$.

According to Inspector $\mathrm{H}$. W LNGE, it exhibits in a certain degree some of the features which are characteristic for the antlers of the 
»Woodland « race; it cannot however, in any way be said to belong to the strongly marked type of this race.

It is a well known fact that there is considerable difference of opinion as to the importance which should be attached to the differences which undeniably exist between the various races of reindeer found in the regions inhabited by these mammals. The older zoologists recognised only one species, the Rangifer tarandus defined by Linné; later authorities, however, both in Europe and America, have found it more correct to subdivide this species into a greater or lesser number of forms which are sometimes - probably by most - only considered as variant races, and sometimes ranked as distinct species. R. Lydekker thus records 6 races, ${ }^{1}$ whereas Madison Grant is of opinion that distinction should be made between 12 »species«. On one point, however, most writers are agreed; viz. in dividing all reindeer into two main groups, the »barren ground or tundra group and the »woodland " group, distinguished according to the nature of the country principally sought by the two groups. This classification however, is naturally not based exclusively upon the nature of their haunts, but also upon certain characteristic features. The barren ground group is thus remarkable for the fact that the horns, which are large in proportion to the size of the animal, are rounded and slender, the beam and tines (including the brow antler) being only slightly palmated; the woodland group, on the other hand, consists of large animals with comparatively small horns, thicker and flatter, the beam and tines, especially the brow tine, being far more palmated. Madison Grant notes as a particularly distinctive feature the tine situated immediately above the brow antler (the lowest tine) which in the case of the woodland group is highly developed and more heavily palmated, contrasting strongly with the comparatively slender, only slightly palmated antler in the barren ground type. ${ }^{1}$ With regard to this distinctive features, however, it should be remembered that the writer in question has himself stated that $\gg$ Antler developement is, if anything, a more variable quantity than either of the preceding characters. There is a wide range of irregularity in the antlers of all deer, reaching what is perhaps its maximum among the various groups of caribou. Animals in the same herd may differ widely in this respect. Even the antlers carried in successive years of an animal's growth may, and often do, vary; and the two antlers of the same animal may not be symmetrical. Nevertheless, within the extreme limits of this irregularity there are certain types of architec-

${ }^{1}$ R. Lydekker, 1898: The deer of all lands; a history of the family Cervidae, living and extinct. London. P. 33-49.

${ }^{2}$ Madison Grant, 1902: 1. c. p. 10. 
ture which though clearly defined, are difficuit to describe. This is true of nearly all the genera of the deer family. ${ }^{1}$

Finally, reference must be made to a reindeer antler found several years ago in a bog at Ondløse Mark, about $14 \mathrm{~km} \mathrm{S.} \mathrm{W.} \mathrm{of} \mathrm{Holbæk}$ (Sealand), on the estate of the former Danish Prime Minister, the late J. B. S. Estrup. According to a communication from him to Jap. Steenstrup the antler was found together with a quantity of »very large leaves «; which unfortunately do not appear ever to have been determinated. The find, and the place where it was made, are mentioned by $\mathrm{H}$. Winge; ${ }^{2}$ beyond this, no information is extant as to the find. A posthumous examination of the papers left by JAP. Steenstrup, however, brought to light a pencil sketch of the antler, with certain measurements, as well as a drawing showing the sequence

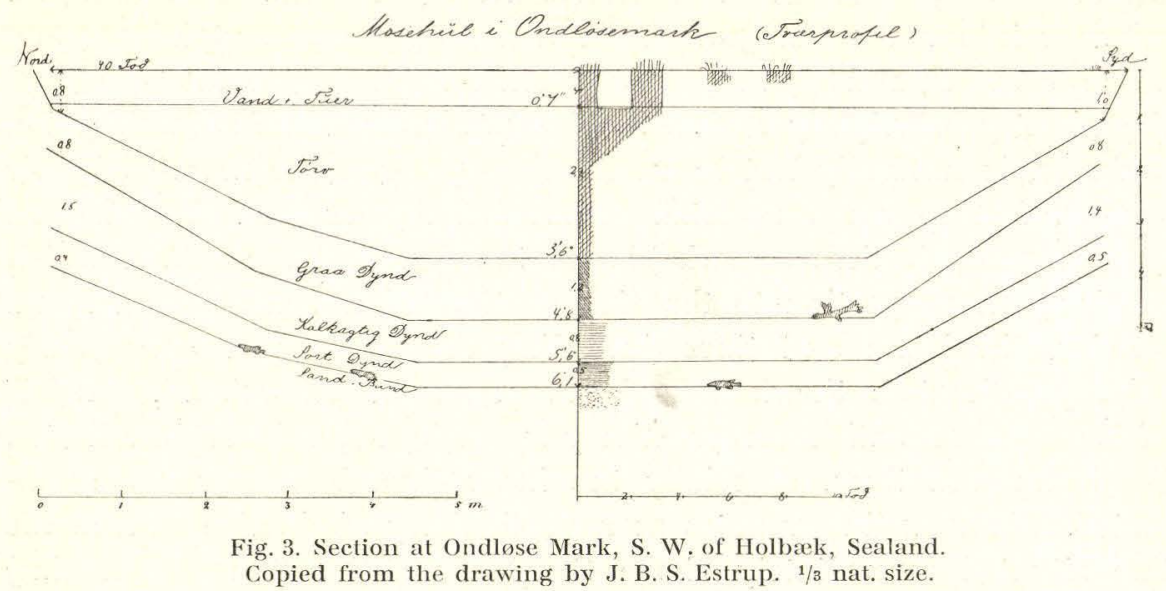

of strata at the spot where it was found. This last named drawing is reproduced in the accompanying figure, Nr. 3. The antler is still kept at the manor-house Kongsdal, but thanks to the kind benevolence of the present owner, Kammerherreinde Mathilde Estrup, a photo of the antler is presented in fig. 4. The distance in direct line from the point of the foremost tine of the crown to the root is $1 \mathrm{~m}$. Length of the beam about $1,20 \mathrm{~m}$. Circumference of the rather flat beam a little above the root $0,17 \mathrm{~m}$. It will be seen that the sketch of the section goes far to compensate for the lack of other information. The profile shows the following strata, commencing from the surface: $0,22 \mathrm{~m}$ water with tufts of grass; $0,91 \mathrm{~m}$ peat, 0,38 grey mud, 0,25 calcareous mud, 0,16 black mud and beneath this sand. We may doubtless presume that the »grey mud « is what would now be called gytie,

1 Madison Grant, 1902: i. c. P. 5.

${ }^{2}$ H. WInge, 1904: 1. c. P. 282. 
the »calcareous mud « being identical with the snail marl frequently found in bogs, as a rule under the peat. It will further be noticed that the reindeer antler is marked on the profile drawing, where it is situated in the lower portion of the gytie (grey mud) just above the juncture with the snail marl, at a depth of $1,5 \mathrm{~m}$. As regards the snail marl, this is, as already mentioned, generally found near the bottom of the basins below the peat; it may, however, also occur

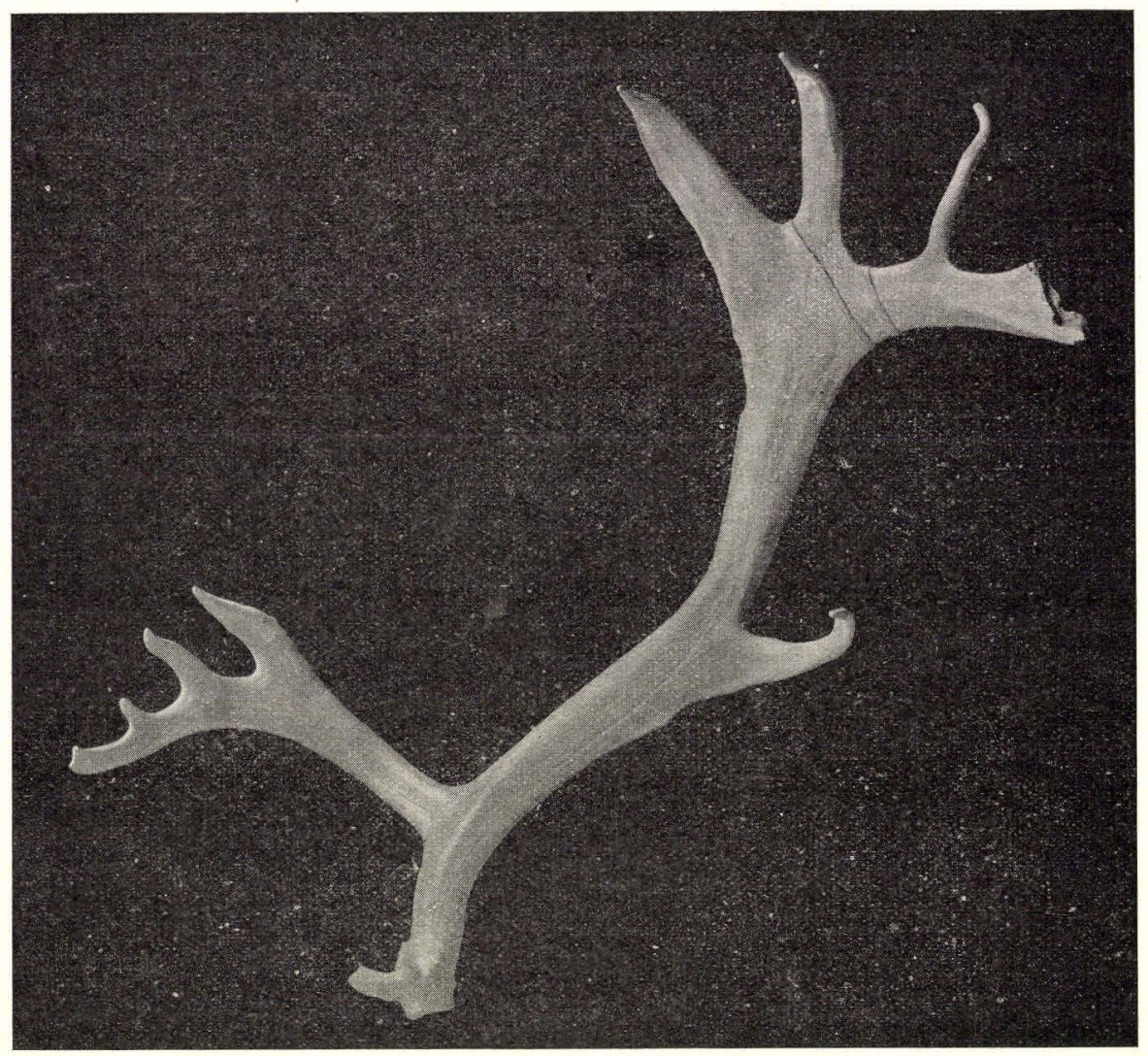

Fig. 4. Right antler of Rangifer tarandus L. from a bog at Ondløse Mark, S. W. of Holbæk, Sealand. 1/10 nat. size.

higher up in the sequence of strata. The formation of this marl is dependent upon an abundant deposit of lime and of great heaps of molluse shells in connexion with a fairly open surface of the water; not, however, on any particular period in the devolopement of the country. We may therefore find snail marl deposits which vary greatly in regard to age. In Denmark, no gytie or snail marl at present known contains flora or fauna of so purely arctic character 
as to warrant the supposition that it was formed under purely arctic conditions. The strata of snail marl examined by A. C. Johansen ${ }^{1}$ belong, in his opinion, to the time from the »aspen period « to that of the oak, or are possibly of even more recent date. Unless therefore the bog at Ondløse Mark can be supposed to form an exception to what is generally known, there is every probability that this antler was shed by an animal which was alive on the spot after the earliest forest growth - that of the aspen and birch - had made its appearance in the country. This probability is further supported by the fact that the calcareous mud is not the oldest fossil-bearing stratum in the bog. In Fig. 3 it will be noticed that three fishes are drawn at the boundary line between the black mud (situate beneath the calcareous mud) and the lowest deposit known, that of the sand. These three marks indicate the places where remains of pike (Esox lucius) were found, thus indicating, in addition to the black colour of the mud, which is doubtless due to vegetable remains, that the water was even at that early date habitable for living creatures. These remains of pike, however, give us unfortunately no information as to the natural conditions under which these strata were formed, as the pike, which is a common inhabitant of our fresh water lakes at the present day, has also been found at several places (e. g. Allerød and Ejby $^{2}$ ) in clay strata with purely arctic flora. - Whether the lowest sand is a lake deposit, or of glaciofluvial origin, it is at present impossible to say.

The foregoing comprises what is known up to now as to the occurrence of reindeer in this country in the alluvial forest period.

As regards the question of $m$ an's existence contemporaneously with the reindeer in Denmark, this will not be further dealt with here. Reference may be made to such works on the subject as our literature presents: (SARAuw, 1904: l. c. p. 303 ff. H. Winge, 1904: 1. c. F. 280 and 284). As the reindeer lived here at the commencement of the forest period, there would be nothing remarkable in the fact of human existence at the same time. A find, not yet published in full, ${ }^{3}$ made in Vendsyssel, would even seem to definitely prove that man and reindeer were both to be found here in the commencement of the alluvial forest period (vide N. Hartz,

${ }^{1}$ A. C. Johansen, 1904: Om den fossile kvartære Molluskfauna i Danmark og dens Relationer til Forandringer i Klimaet. I. Land- og Ferskvandsmolluskfaunaen. Copenhagen. Inaug. Dissert.

${ }^{2}$ N. Hartz, 1902: Bidrag til Danmarks senglaciale Flora og Fauna. Avec résumé en français. Danm. geol. Undersøg. II. R. Nr. 11.

${ }^{3}$ The treatise will be published in Danm. geol. Undersøg. II. R. Nr. 29. 
1914: Nye Fund i de senglaciale Ferskvandslag ved Nørre Lyngby [Referat af Foredrag] Meddel. Dansk Geolog. Forening, Copenhagen. Bd. 4, p. 305).

\section{Traces of beaver.}

In the course of the excavation above referred to as having been made in the bog at Kjellerup near Ringe, another find was

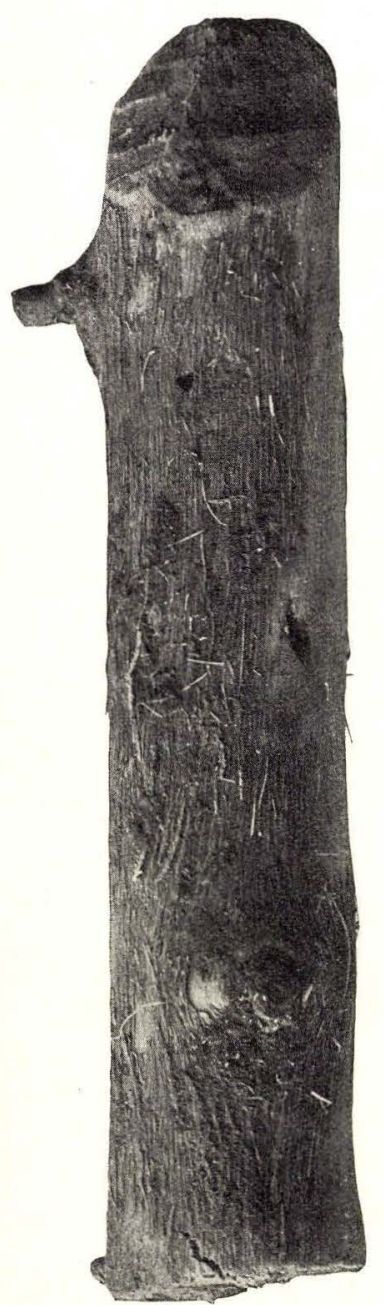

Fig. 5. Twig of aspen (Populus tremula) gnawed by beaver Nat. size. Bog at Kjellerup SE of Ringe, Funen. made, which likewise possesses a certain interest. In the very lowest portion of the Amblystegium peat, about $0,95 \mathrm{~m}$ below the surface, and about $0,20 \mathrm{~m}$ below the reindeer antler, a twig of aspen (Populus tremula) 13 $\mathrm{cm}$ long and $2,5 \mathrm{~cm}$ thick was found, and kindly determined by Prof. O. G. Petersen. The twig (Fig. 5) exhibited at one end distinct traces of the incisors of a beaver, Castor fiber, and was in addition shaped in exactly the same manner as the branches bitten off by the beavers for use in construction work, for instance of shelters, dams, etc. The bark was almost entirely removed. It may be mentioned that in the course of an examination made by Cand. Knud Jessen in 1914, i. e., several years later, several grains of pollen of Pinus sylvestris were found in the small lumps of moss peat which still adhered to the twig, which had been preserved in spirits without having been fully cleaned. This incontrovertible proof of the presence of beavers is interesting inasmuch as it shows this animal to have been a contemporary of the reindeer in Denmark, and justifies the suggestion previously made ${ }^{1}$ that the beaver was an early inhabitant here, a theory put forward on the basis of its present geographical distribution and habits of life. This theory had not hitherto been borne out by the remains of beaver which had not

\footnotetext{
${ }^{1}$ Herluf Winge, $1904:$ l. c. p. 302.
} 
infrequently been found in our bogs, as in most cases it was not known to what period of vegetation and climate they belonged. That the beaver had lived here in the »oak period « was proved by the finding of gnawed branches, as for instance in the bog at Stevningen, north of Svendborg (Funen). Some branches of alder (Alnus glutinosa) and elm (Ulmus montana) from this locality are shown on a reduced scale in Fig. $6,{ }^{1}$ which distinctly reveals the way in which the ends
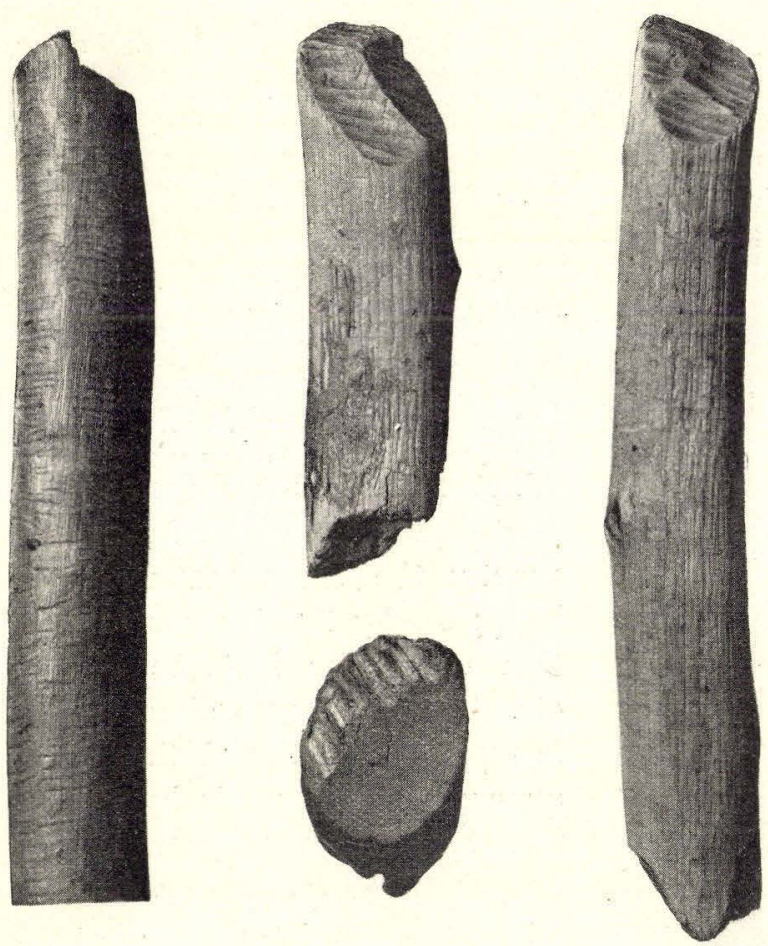

Fig. 6. Branches of Alnus glutinosa and Ulmus montana gnawed by beavers. $2 / 5$ nat. size. Slevningen bòg N. of Svendborg, Funen. (Nordmann: D. G. U. III. R. Nr. 5),

have been gnawed off slantwise and sharpened, with the broad marks of the animal's incisors as well as the faint marks round the outside of the branch, made by the beavers in removing the bark. The fact of the beaver's early immigration into Denmark after the last glacial period, first demonstrated by the find at Kjellerup, has since been

1) In D. G. U. III. R. Nr. 5 and III. R. Nr. 2, 3th edition 1913 the branches figured above have been mentioned as branches of oak; a later examination, made by KNud Jessen, has shown that they belong to alder and elm. 
further confirmed by other finds: it has even been proved, as mentioned on p. 4 that it was to been found here during the late glacial temperature optimum, the Allerød oscillation, numerous beaver-gnawed branches and twigs having been found in the so-called Allerød mould and Allerød gytie in the bog at Femsølyng in the north of Sealand. ${ }^{1}$ It has also been shown - as likewise noted on p. 5 that the beaver formed part of the Danish interglacial fauna, beaver sticks having been found in bogs from the latest interglacial period in Jutland. Fig. 7 shows - in $1 / 3$ natural size an excellently preserved pine stem (Picea excelsa) which has been worked by the beaver. This tree has not existed in a wild state in Denmark after the latest glacial period: its remains are characteristic of our interglacial fresh water deposits. The find in question was made by Dr. N. Hartz in an interglacial bog at Tuesbøl Mark near Brørup, about $30 \mathrm{~km}$ West of Kolding.

As to when the beaver became extinct or was exterminated in Denmark, nothing is known with certainty. That it still existed, and was hunted by man, in the earlier kitchen midden period is sufficiently evident from the presence of bones in the great refuse heaps, while a certain place name, Bæverskov = Beaver wood (in Sealand) seems to support that

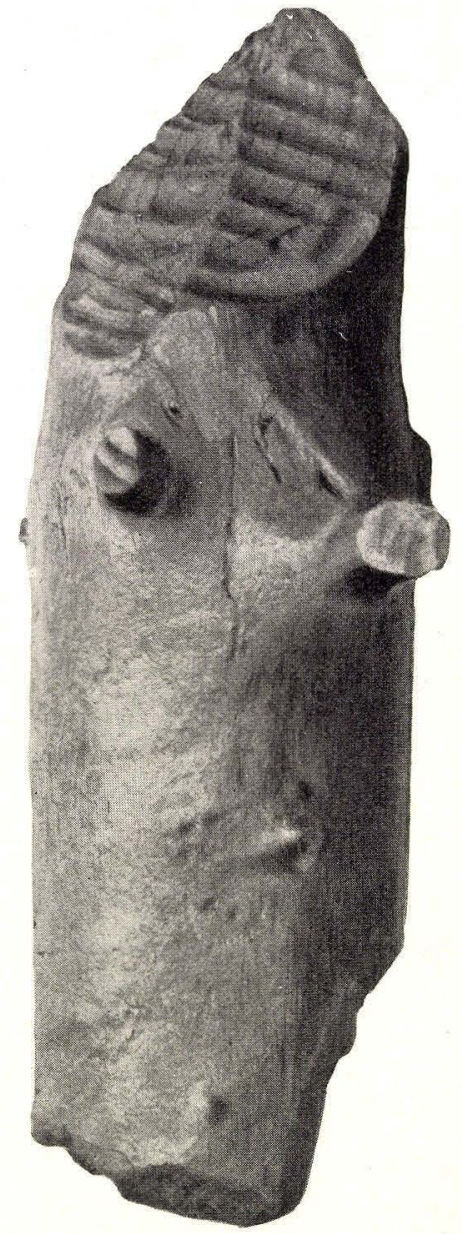

Fig. 7. Stem of Picea excelsa gnawed by beaver. About $3 / 4$ nat. size. From an interglacial bog near Brorup. $30 \mathrm{~km} \mathrm{~W}$ of Kolding, Julland. it must have lived here until somewhere near the commencement of historical times.

${ }^{1}$ N. Hartz, 1912: Allerød Gytje und Allerød Mull. Meddel. Dansk Geol. Forening, Copenhagen. Bd. 4 , p. 88. 


\section{Explanation to the scheme.}

In the scheme an attempt is made to give a general view of the post-glacial (i. e. the late-glacial and alluvial) periods in Denmark compared with those of Scandinavia. It is a matter of course that the limits shown in the scheme do not exist in that distinct manner in Nature, nor are the corresponding periods quite contemporary over the whole Northern Europe; when - for instance - the arctic or subarctic floras were flourishing in the Northern or even in the central parts of Sweden, forests of fir and the accompanying plants were advancing in the Southern parts. Where the limits are more than usually uncertain, they are marked only by a dotted line. The dimensions of the rubrics do not by any means indicate the relative duration of the period in question, nor will the zigzag line in the second column indicate the relative magnitude of the elevations or submersions.

The fifth column contains inter alia the division of our forest periods given in 1841 by $\mathrm{J}_{\mathrm{AP}}$. Steenstrup, a division hitherto commonly used but now obsolete, as being no longer adequate to the more exact fixation of time for archeological and palaeontological finds.

The seventh column contains the most characteristic species of animals and plants, especially those which indicate extreme temperature conditions. Several of the named animals and plants are however not confined to that precise period in which they are placed here. Besides the mammals mentioned on page 3 as extinct in Denmark, the following animals and plants named in the scheme have since disappeared from Denmark: Portlandia arctica, Tellina Torelli, T. Loveni, Planorbis Stroemii, Tapes decussatus, T. aureus, T. edulis, Dosinia exoleta, Lutraria elliptica, Psammobia vespertina, Salix polaris, $S$. reticulata, Dryas octopetala and Betula nana.

The division is founded upon the investigations published in the literature, the chief papers of which are quoted in the treatises of 
G. Andersson, J. Holmboe, V. Nordmann, R. Sernander and P. A. Øyen in: Die Veränderungen des Klimas seit dem Maximum der letzten Eiszeit. Eine Sammlung von Berichten herausgegeben von dem Executivkomitee des 11. internationalen Geologenkongresses. Stockholm 1910. Further publications are to be found and quoted) in :

R. Sernander, 1908: Report of Lewis: The plant remains in the Scottish peat mosses I, II and III. Geolog. Fören. Stockholm Förhandl. Vol. 30, p. 262 ff.

V. Nordmann, 1911: Allerød-Oscillationen og Kristianiafjordens senglaciale Dannelser. Meddel. Dansk geologiske Forening. Bd. 4. 1912. p. 94.

J. V. Eriksson, 1912: Bälinge mossars utvecklingshistoria och vegetation. Résumé in Deutscher Sprache. Svensk Botanisk Tidsskrift. Vol. 5.

K. O. Влørlyкке, 1913: Norges Kvartærgeologi. With an English summary. Norges geolog. Undersøgelse, Nr. 65.

P. A. Øyen, 1913: A fossil-bearing deposit of the Mactra-niveau in Christiania. Kristiania Vidensk.-Forhandl. Nr. 5.

P. A. Øyen, 1913: Transitional quaternary strata of Bentse, Christiania. Ibidem Nr. 6.

L. vox Post, 1913: Über stratigraphische Zweigliederung Schwedischer Hochmoore. Sveriges geolog. Undersökning. Årsbok 6 (1912) Nr. 2.

A. G. Нӧgвом, 1913: Fennoskandia. Handbuch der Regionalen Geologie. IV. Bd., 3. Abt.

R. Sandegren, 1915: Ragundatraktens postglaciala utvecklingshistoria enligt den subfossile florans vittnesbörd. Mit Resümee in Deutscher Sprache. Sveriges geolog. Undersökning. Ser. Ca, Nr. 12.

The starting point for the division of the late-glacial time is taken in the Allerød period, the first temperature and climatic optimum since the last glacial period, proved in 1901 by N. HARTz and V. Milthers in the brickfield pit at Allerød in Northern Sealand and in the following years at several places in Denmark, Sweden and Northern Germany from Bornholm to Holstein. In 1910 I hinted at, and in 1911 set forth my reasons for supposing the correspondence and contemporaneity of the Allerød deposits and some of the late-glacial marine deposits in the Christiania region (a paper read in Dansk Geologisk Forening 3. April 1911, published 1912). At the request of Mr. Øyen I sent him after the meeting a report of my views of that matter, and soon afterwards he published similar opinions (Norsk Geologisk Tidsskrift II, Nr. 7, p. 47, 1911) without mentioning our 
correspondence. In the 13 th column of the scheme I have inserted he Allerød period in H. Munthe's History of the Baltic (published 1910 in Henr. Munthe: Studier öfver Gottlands senkvartära historia. Sveriges geolog. undersøkn. Ser. Ca, Nr. 4. With an English Summary of contents) and in the 10th column the Allerød period in Scania shown by N. O. Houst (1910: De senglaciale lagren vid Toppeladugård. Geol. Fören. Stockholm Förhandl. Vol. 28) is inserted in the scheme of R. Sernander. 
The postglacial periods of Denmark, compared with those of Norway and Sweden.

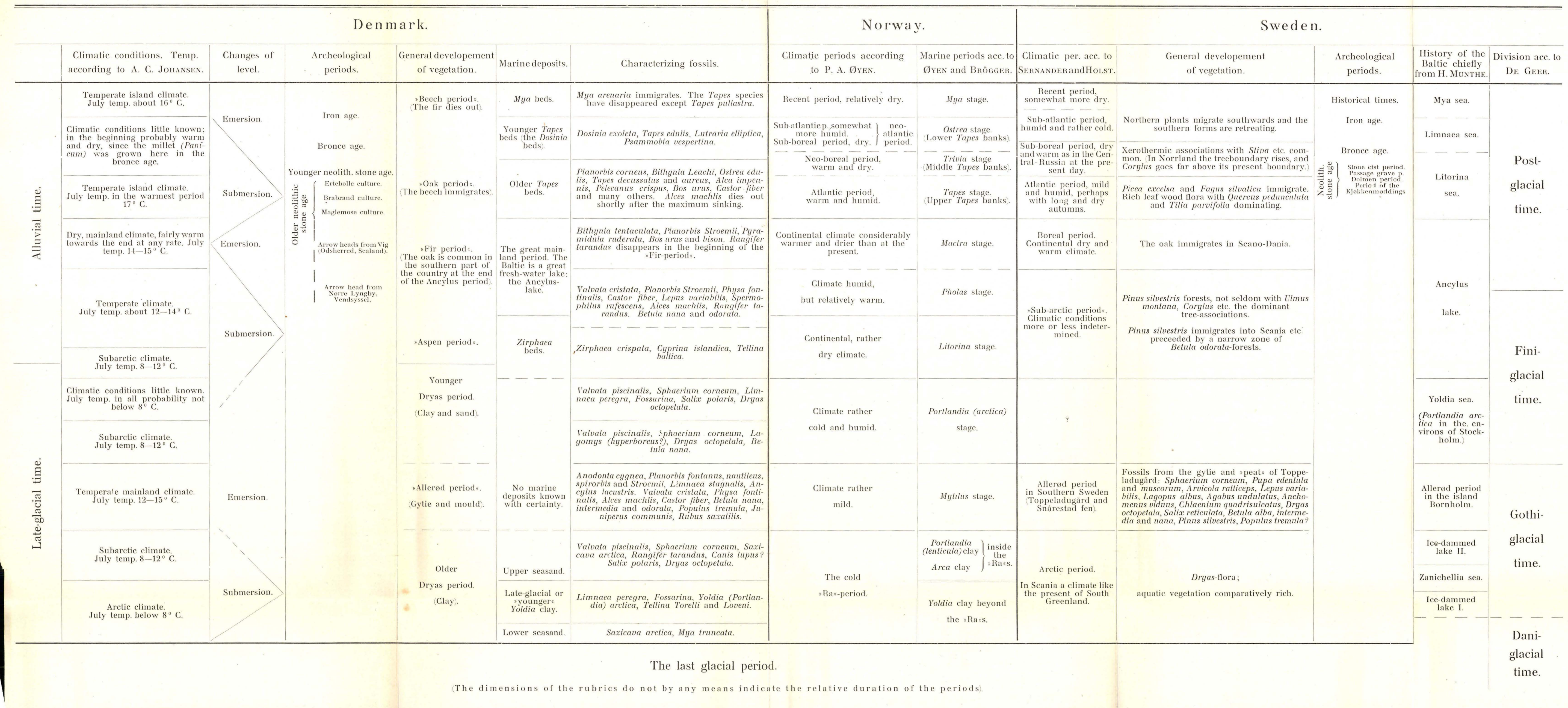


Nr. 6. K. Rørdam. Kridtformationen i Sjælland i Terrænet mellem Kjøbenhavn og Køge og paa Saltholm. 1897. $1,50 \mathrm{Kr}$.

7. K. Rørdam og C. Bartholin. Om Forekomsten af Juraforsteninger i løse Blokke i Moræneler ved Kjøbenhavn. 1897. - 0,75 Kr.

- 8. Ethel G. Skeat and Victor Madsen. On Jurassic, Neocomian and Gault boulders found in Denmark. 1898. - 4,00 Kr.

- 9. N. Hartz og E. Østrup. Danske Diatoméjord-Aflejringer og deres Diatoméer. 1899 . $-1,25 \mathrm{Kr}$.

- 10. Bidrag til Bornholms Geologi I. - K. A. Grönwall: Bemærkninger om Bornholms sedimentære Dannelser og deres tektoniske Forhold. J. P. J. Ravn: Trilobitfaunaen i den bornholmske Trinucleusskifer. A. Нловтн: Om Vellengsbyleret og dets Flora. N. V. Ussing: Sandstengange i Granit paa Bornholm. 1899. $-1,75 \mathrm{Kr}$.

- 11. N. Hartz. Bidrag til Danmarks senglaciale Flora og Fauna. 1902. $-2,00 \mathrm{Kr}$.

- 12. N. V. Ussing. Mineralproduktionen i Danmark ved Aaret 1900. 1902. - 2,00 Kr.

- 13. Karl A. Grönwall. Bornholms Paradoxideslag og deres Fauna. 1902. - 6,00 Kr.

- 14. Victor Madsen. Om den glaciale, isdæmmede Sø ved Stenstrup paa Fyn samt om Dannelsen af Teglværksleret i Stenstrup-Egnen. 1903. - 2,00 Kr.

- 15. Karl A. Grönwall. Forsteningsførende Blokke fra Langeland, Sydfyn og Erø, samt Bemærkninger om de aldre Tertiærdannelser $\mathrm{i}$ det baltiske Omraade. 1904. - 1,75 Kr.

- 16. N. Steenberg og Poul Harder. Undersøgelser over nogle danske Sandsorters tekniske Anvendelighed. 1905. $0,35 \mathrm{Kr}$.

- 17. Victor Madsen, V. Nordmann og N. Hartz. EemZonerne. Studier over Cyprinaleret og andre EemAflejringer i Danmark, Nord-Tyskland og Holland. 1908. - 6,00 Kr.

- 18. Karl A. Grönwall og Poul Harder. Paleocæen ved Rugaard i Jylland og dets Fauna. 1907. - 2,50 Kr.

- 19. Poul Harder. En østjydsk Israndslinje og dens Indflydelse paa Vandløbene. 1908 . $-6,00 \mathrm{Kr}$.

- 20. N. Hartz. Bidrag til Danmarks tertiære og diluviale Flora. 1909. - 6,00 Kr.

- 22. Poul Harder. De oligocæene Lag i Jernbanegennemskæringen ved Aarhus Station. 1913. - 5,00 Kr.

- 23. V. Milthers. Scandinavian Indicator-Boulders in the Quaternary Deposits. 1909. - 3,00 Kr.

- 24. C. T. Bartholin. Planteforsteninger fra Holsterhus paa Bornholm. 1910. - 1,25 Kr. 
Nr. 25. A. Jessen, V. Milthers, V. Nordmann, N. Hartz og A. Hesselbo. En Boring gennem de kvartære Lag ved Skærumhede. Undersøgelse af en Forekomst af naturlig Gas i Vestjylland. $1910 .-4,00 \mathrm{Kr}$.

- 26. K. Brünnich Nielsen. Crinoiderne i Danmarks Kridtaflejringer. $1913 .-5,00 \mathrm{Kr}$.

28. V. Nondmann. On Remains of Reindeer and Beaver from the commencement of the Postglacial Forest Period in Denmark. With some remarks upon other Danish quaternary mammals and a scheme: The postglacial periods of Denmark, compared with those of Norway and Sweden. 1915 . $-0,75 \mathrm{Kr}$.

\section{Række.}

\section{Beretninger og almenfattelige Fremstillinger.}

Nr. 1. Oversigt over de af Danmarks geologiske Undersøgelse indtil Foraaret 1895 udførte Arbejder. 1896. - 1,00 Kr.

- 2. N. V. Ussing. Danmarks Geologi i almenfattelig Omrids. Tredie Udgave ved Poul Harder. 1913. - 4,50 Kr.

- 3. V. Muthers. Foreløbig Beretning om en geologisk Rejse i det nordøstlige Tyskland og russisk Polen, foretaget i Forsommeren 1901. 1902. - 0,25 Kr.

- 4. V. Milthers. Grundvand og vandførende Lag i Danmark, særlig med Henblik paa Forsyningen af Brønde. 1903. $-1,50 \mathrm{Kr}$.

- 5. V. Nordmann. Danmarks Pattedyr i Fortiden. 1905. $2,00 \mathrm{Kr}$.

- 6. Oversigt over de af Danmarks geologiske Undersøgelse i Aarene 1895-1904 udførte Arbejder. 1905. - 1,00 Kr.

- 7. Forhandlingerne i Udvalget for landøkonomiske Jordbundsundersøgelser samt Oversigt over landøkonomiske Arbejder i 1911 - 12. 1912. - 0,50 Kr.

- 8. Oversigt over de af Danmarks geologiske Undersøgelse i Finansaaret $1912-13$ udførte landøkonomiske Arbejder. 1913. - $0,25 \mathrm{Kr}$.

- 9. V. Milthets og. Th. Claudi Westh. Viborg Egnens Mergellag, deres geologiske Omgivelser og deres Udnyttelse. 1913 . $0,25 \mathrm{Kr}$.

- 10. Oversigt over de af Danmarks geologiske Undersøgelse i Finansaaret 1913-14 udførte landøkonomiske Arbejder. 1914 . $-0,25 \mathrm{Kr}$.

- 11. V. Milthers. Mergel og Kalk i det nordvestlige Jylland. 1914. $-0,50 \mathrm{Kr}$.

- 12. Oversigt over de af Danmarks geologiske Undersøgelse i Finansaaret 1914-15 udførte landøkonomiske Arbejder. 1915 . $-0,25 \mathrm{Kr}$. 